\title{
Development of Company Value Based Digitalization: A Study At State Owned Water Company
}

\author{
Bima Hermastho and Muhammad Ricza Irhamni \\ Management, Faculty of Economics, Wahid Hasyim University \\ *Email: ricza@unwahas.co.id
}

\begin{abstract}
Digitalization management company is a very important condition for increasing competitiveness of company. With the use of digital technology, companies need a change in management process and in the work processes of employee. Researchers have highlighted this as an interesting topic of discussion, and a challenge for companies, including regional water companies. This paper analyzes development of management digitalization in state owned water company. And get the results company value design of state owned water company based digitalization.
\end{abstract}

Keywords: Digitalization, Company Value, Digital Technology and State Owned Water Company.

\section{INTRODUCTION}

The development of digital technology and changes in the very dynamic business environment require human resources to be able to adapt continuously, both in terms of technical competences, leadership and core competencies. Likewise, attitudes must always change, including in serving customers who must be much better because customers must have a pleasant experience from a service, employees must also work independently and be able to collaborate on projects and maintain company compliance with applicable regulations (e2consulting, 2020).

Since 2006, the European Parlement has stated importance of digital competence in a company. Digital competence is key that enables people to acquire various kinds of knowledge. Everyone is also required to be skilled in digital competencies, in order to ensure that everyone is able to actively participate in the social and economic life of a country (Ferrari, 2013).

Management digitalization has now influenced dynamics of company's business model, both in product and service business. And stakeholders must now be able to adjust their managerial abilities to face these challenges, which include increasing customer needs and customer privacy concerns (Valentina V. Gerasimenko \& Razumova, 2020). Moreover, for state owned water company customers, customer orientation is one of important things and must be priority of state owned water company.

Gauthier et al., (2018) states that each stakeholder must have at least three main skills contained within himself, namely information technology skills that can be used to solve internal company problems, strategic skills to deal with external challenges and also special skills in new business models which are used as synchronization between internal problems and external to company.

In addition stakeholders, mastery of digital competencies is also very important for development skills for every employee who is a member of the company, which can improve employee competence, increase customer satisfaction and also meet customer needs (V. Gerasimenko et al., 2015; Pięta, 2018). It's becoming increasingly clear why digital competence is highly highlighted by European Parliament in list of competencies that are very important for every company in carrying out its business sustainability (Valentina V. Gerasimenko \& Razumova, 2020).These competencies based digitals will be used to develop the values of State Owned Water Company.

\section{Company Digitalization}

Digitalization or digital transformation is able to drive change in world of business, in today's era many businesses are building new internet-based technologies that aim to provide satisfaction to society (Unruh \& David Kiron, 2017). Digitalization is able to provide changes the 
organization, because technological advances will certainly have an effect on improving organizational performance (Westerman et al., 2011).

Bloching et al., (2015) defines digital transformation as continuity between economic actors and needs of digital economy on an ongoing basis. While Unruh \& David Kiron, (2017) defines digitalization as restructuring of economy in an organization and in society, which is useful for increasing work efficiency.

Digitalization itself can develop in such a way due to technical evolution in use of technology in a society or technicality in organizations. The digital world can increasingly be sustainable to complement each other in completing work, so that there will be more efficiency in work (Linz et al., 2017).

Many changes in an organization or company have been caused by digitalization, and one of them can cause changes to the business model of an organization (Matzler et al., 2016). In the process of changing business model, initially there are companies that have dominated market and will face new competitors with a new technology, after which the companies that have dominated the market will update their technology and so that in the end a new business model based on digitalization itself will be formed (Linz et al., 2017; Matzler et al., 2016).

In the end, companies that work in any field must innovate business models based on digital or technology world, in order to be able to compete with the market or meet needs of their customers (Chesbrough, 2010; Linz et al., 2017).

\section{Company Values}

Company values are one way for a company to achieve its competitive advantage (Özçelik et al., 2016), organizational values are also defined as one of ways that organizations carry out their organizational culture. Values can be used as basis of organizational culture to drive company performance. Value is defined as the main desire or belief that is desired at end to transcend certain situations, this belief which will later guide us to act directly or indirectly in organization, and which will later become a character (Antonio Argandona, 2002).

Values are able to control activities, individual behavior at work to achieve common goals in the organization. In addition, values become important related to strategic issues, attention to change (especially on digital change) and positive organizational performance (Brinkley RW, 2013).

Values have a dynamic nature and can be adopted in different forms, these values can be adopted and announced publicly by top managers on behalf of organization which aims as a reference for future (Schein, 2004). Values can also be shared beliefs, such as when most employees are asked about the beliefs they believe in, and organizations can adopt from these (Özçelik et al., 2016).

Fitzgerald \& Desjardins (2004) argues that values are able to provide important insights to establish a work environment and foster a culture that is goal-oriented to achieve organizational performance.

\section{Digitalization of Company Value}

This perspective on digitalization and firm values is combined in context of dynamic capabilities, which are contained in the conceptual framework of this empirical study. The conceptual framework of this study can be seen in Figure 1 of this study.

Adjusting to market needs or market dynamics itself, after that there is formation of vision, strategy and competence of organization (company value) itself. And interconnected between market dynamics to development of new technologies used in the company. 


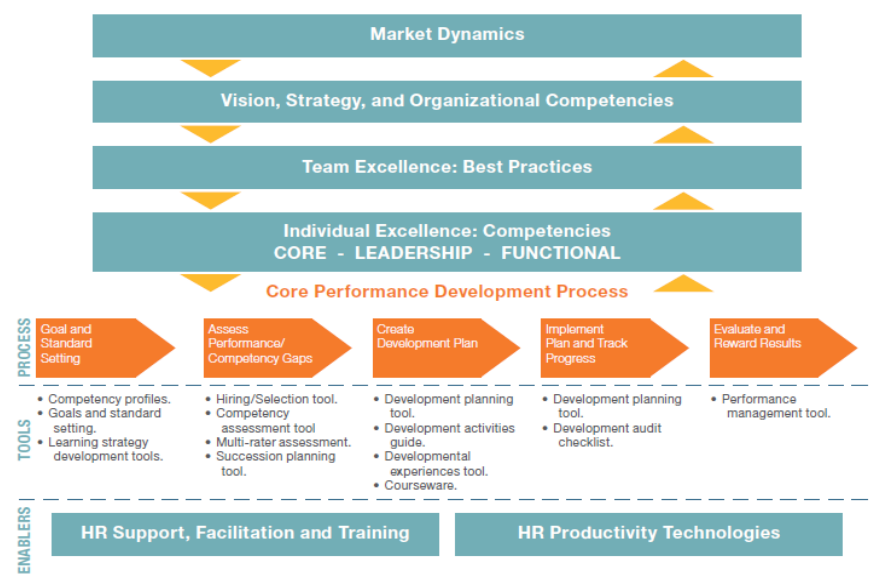

Figure 1. Conceptual Framework

\section{RESEARCH METHOD}

The main objective of this study is to determine whether the company values of state owned water company are able to develop and adapt to digitalization. Thus, the company is able to improve company performance by forming new company values based on digitalization. Of course, it will further increase the effectiveness and efficiency of organization as well.

The sample used in this study is in form of company values or core competencies of state owned water company, in this case 5 (five) company values were taken as sample of this study which includes 9 (nine) aspects of company's core competencies of state owned water company. Thus, the statements of core competency aspects are explored in depth and are used as focus of this research.

The statement of company values and their aspects is taken directly from company state owned water company, which is listed in standard guidebook for company organizational competence. The aim is to understand contextual of these sentences and to explore how the competencies and abilities of employees at state owned water company work out.

Each component of company values is examined one by one in this study, for example, the first aspect of company value is "customer focus". Customer focus refers to the extent to which organization's commitment to responding and satisfying customer concerns about quality and timeliness of their orders and fulfilling their demands for products and services is maximized (Pine et al., 1993), and much more.

After all components are defined, it will be possible to know what components are needed and can be added to complement 9 (nine) aspects of company value in state owned water company here.

\section{ANALYSIS AND RESULTS}

The company values that will be analyzed here are described one by one along with aspects they have, along with proposed aspects given to build digitalization of the state owned water company.

Table 1. Changes Company Value Based Digital

\begin{tabular}{|l|l|}
\hline Old Company Value & New Company Value \\
\hline $\begin{array}{l}\text { Satisfaction; } \\
\text { a. Customer Focus }\end{array}$ & $\begin{array}{l}\text { Satisfaction; } \\
\text { a. Customer Focus } \\
\text { b. Communication } \\
\text { c. Digitalization Management } \\
\text { System }\end{array}$ \\
\hline $\begin{array}{l}\text { Morale; } \\
\text { a. Achievement Motivation }\end{array}$ & $\begin{array}{l}\text { Morale; } \\
\text { a. Achievement Motivation } \\
\end{array}$ \\
& b. Accountability \\
& c. Adaptation \\
& d. Team Work \\
\hline
\end{tabular}




\begin{tabular}{|l|l|}
\hline $\begin{array}{l}\text { Integrity; } \\
\text { a. Integrity }\end{array}$ & $\begin{array}{l}\text { Integrity; } \\
\text { a. Self Development } \\
\text { b. Coaching } \\
\text { c. Modern Management }\end{array}$ \\
\hline $\begin{array}{l}\text { Leadership (be a role model); } \\
\text { a. Leadership } \\
\text { b. Interpersonal Skill }\end{array}$ & $\begin{array}{l}\text { Leadership (be a role model); } \\
\text { a. Leadership } \\
\text { b. Interpersonal Skill } \\
\text { c. Environmental }\end{array}$ \\
\hline $\begin{array}{l}\text { Enterpreneurship; } \\
\text { a. Continuous Imrovement } \\
\text { b. Independently } \\
\text { c. Global Insight }\end{array}$ & $\begin{array}{l}\text { Enterpreneurship; } \\
\text { d. Open Minded }\end{array}$ \\
& $\begin{array}{l}\text { b. Independently } \\
\text { c. Global Insight }\end{array}$ \\
d. Open Minded \\
\hline
\end{tabular}

\section{Satisfaction}

In general, consumer satisfaction is a phenomenon after a service or purchase is made, consumer satisfaction can occur before buying or even when not making a purchase, for example someone is dissatisfied with an out-of-town supermarket that never makes restrictions because it can cause local shops to close (Giese \& Cote, 2002).

Aspects of company value "satisfaction" here there is one aspect, namely "customer focus". Customer focus itself refers to extent to which organization's commitment to responding and satisfying customer concerns about quality and timeliness of their orders and fulfilling their demands for products and services is maximized (Pine et al., 1993).

And with digitalization of company values, aspects of satisfaction are added to two more aspects, namely "Digitalization of Management Systems" which aims to automate every work system related to customers and for that it also needs another aspect for performs a coordination function, namely "Communication" aspect.

The digitalization of management system itself is procedure for an organization to shorten work of an employee and manage all service data or company data in a computerized manner. With digitalization of management system, it is hoped that organization will be able to provide faster service and increase customer satisfaction.

While communication itself is defined as delivery of information and understanding using verbal and non-verbal symbols carried out between a person or group against another person or group (Riggio, 2009). With improvement of good communication, it is hoped that all employees will be able to prioritize consumers and be able to provide appropriate communication with what consumers expect, so that there will be no misunderstanding or customer dissatisfaction.

\section{Moral}

Moral is often defined as capacity of group members to maintain institutional beliefs or goals, especially in face of opposition or difficulties. According to Alexander H. Leighton (1949) morality is ability of a group of people to work together continuously and consistently in pursuit of goals to be achieved together.

This "moral" company value has one aspect to shape company's value, namely "achievement motivation". Where motivation itself is direction of a person's behavior or what causes someone to want to repeat a behavior, a group of forces that act behind of motive. Individual motivation can come from other people (extrinsic events) or can also come from oneself (intrinsic events) (Ryan \& Deci, 2000). While achievement itself is a result of efforts made by someone.

With digitalization of corporate value, it is necessary to add aspects to corporate moral values, namely "accountability, adaptation and teamwork".

Accountability itself is clarity of functions, implementation and responsibilities of individuals or companies, so that management is carried out effectively. The principle of accountability provides clarity of rights and obligations between shareholders, the board of 
directors and board of commissioners. With accountability, employees are expected to be able to provide clarity and be able to be responsible for work they do, not only because of an obligation.

Besides that, there is also adaptation, adaptation is an adjustment to new environmental conditions, or it can be interpreted as adjustment of a material according to needs, changing a material from old into a new form. With adaptation to aspect of company value, it is hoped that employees will be able to adjust themselves to use of new technologies and be able to utilize them to maximize work results.

Furthermore, in moral, there is teamwork, which means that with teamwork included in aspect of company values, each employee is expected to be able to do work simultaneously. This, of course is outside of jobs that have become responsibility of themselves or work of each individual.

\section{Integrity}

Integrity is often defined as one's adherence to moral principles in capturing essence of ethical values contained in organization (Palanski \& Yammarino, 2011). The company's value of "integrity" has one aspect in enhancing integrity of an employee, namely aspect of integrity itself.

With concept of digitizing corporate value, value of integrity needs to be added to several aspects and eliminating existing aspects, because existing aspects are same as the intended company value. And aspects that are added are "self-development, coaching and modern management".

Self-development includes all activities that increase self-awareness and identity, develop talents and potential, build human resources and facilitate performance, improve quality of life and contribute to realizing dreams and aspirations. In the concept of self-development there are absolutely no restrictions, the concept can include formal and informal activities (Bob Aubrey, 2010). In this case, employees of state owned water company are expected to be able to develop themselves individually or in their organizational groups.

In addition there is also coaching, coaching is an effort to formal and non-formal education that is carried out consciously, planned, directed and responsibly in order to introduce, grow, guide and develop a balanced, whole and in line with appropriate knowledge and skills with talent. Tendency or desire and ability as a provision, and subsequently to improve and develop themselves (Simanjuntak \& I. L Pasaribu, 1990). In this context, each employee is expected to be able to foster other employees whose knowledge or abilities are still below standard, so that employees can build each other towards faster improvements.

And then there are aspects of modern management, modern management argues that the organization is not a closed system related to a stable environment, but organization is defined as an open system that must adapt to changes in its environment. In other words, modern management theory is a system of increasing flexibility in technology or other developments in an organization (Riyanti Etania, 2020). In this case, employees are expected to be able to adapt to development of modernization in form of technology or other things that can support the progress of organization.

\section{Leadership (Being Role Model)}

Leadership is defined as a process of social influence where a person can ask for help and support from others in completing shared tasks (Chemers, 1997; Chin, 2015). Value of the company "leadership (being role model)" in this study has two aspects in it, namely leadership itself and interpersonal skills.

With concept of digitizing company values, in this case the concept of leadership needs additional aspects, namely the aspect of "environmental empowerment". It is hoped that the company will be able to maintain stability of existing environment and be able to manage water needs used as main product of company.

Leadership as described above by Chemers (1997) and Chin (2015). However, in this concept, every employee is expected to be able to develop their own leadership abilities. Where self-leadership is developing a person's feelings about what that person wants to achieve, about person's goals by managing person's emotions, behavior and communication to achieve their goals. This is often defined as how a person is motivated to be able to develop himself (Browning, 2018). 
In this context, employees are expected to be able to manage their abilities individually, and to be able to make arrangements or influence others in accordance with leadership functions themselves.

Next, it is about interpersonal skills, where these interpersonal abilities are behaviors and tactics a person uses to interact with others effectively. In business world, the term refers to an employee's ability to work well with other people (Evan Tarver \& Brock, 2020). In this case, employees are expected to be able to develop the ability to interact with other people effectively at work and in world outside of work.

The next thing its about environmental empowerment, environmental empowerment itself is a common goal so that it must also be created jointly (Yasril \& Nur, 2018). Environmental empowerment aims to protect and manage environment, in this scope employees are expected to be able to contribute in caring for environment in order to maintain sustainability of clean water used as a staple product by company.

\section{Entrepreneurship}

Entrepreneurship is defined as process of designing, launching and running a new business, which is often initially a small business, or as the capacity and willingness to develop, organize and manage a business venture along with all its risks to generate profits (Alvarez \& Busenitz, 2001). Value of the company "entrepreneurship" in this case has four aspects, these aspects are continuous improvement, independent, global insight and open thinking.

With concept of digitalization, in this case it is necessary to add an aspect of entrepreneurial value, namely aspect of achieving targets. In this case, it is expected that each employee will be able to contribute in achieving targets and can improve their work results for the company.

Continuous improvement is often defined as a never ending gradual change, which focuses on increasing the effectiveness and/ or efficiency of organization to meet its policies and objectives, not limited to quality initiatives, improvements in business strategy, business results, customer relations, employees and suppliers can continue. improved. Simply put, this means getting better all the time (Fryer et al., 2007). In this context, employees are expected to be able to improve their abilities to improve themselves continuously (continuously), in order to improve abilities of each employee individually.

Next function is aspect of independently, independently or independence itself is readiness and ability of individual to stand on his own, which is marked by taking the initiative. In addition, trying to solve problems without asking for help from others, trying and directing behavior towards perfection (Serafica Gischa, 2020). In this context, employees are expected to be able to solve of problems they face themselves and to be able to complete their tasks quickly. Employees are also expected to be able to take the initiative to improve their abilities and skills.

Other aspects also have a global perspective which is added in this context, having a global perspective has a broad meaning, meaning that employees are not only knowledgeable in terms of their job duties, but also know what is the duty or job of others and understand work and issues. global or worldwide issues.

In the next aspect contained in value of entrepreneurship is open thinking, an open minded person is defined as a person who typically moves beyond or temporarily overrides his or her own commitment to provide a fair hearing and is impartial to intellectual opposition (Baehr, 2013). According to Kwong (2016) seen open mindedness as a willingness to take a new perspective seriously. In this context, employees are expected to be able to see from all perspectives that exist when there is a certain problem, this is so that there are no misunderstandings between employees with one another.

The last aspect in the entrepreneur value's of this company is achievement of targets, the target itself is a goal to be achieved, where this goal has never been achieved before (Iman, 2020). In the aspect of emphasizing that employees can find desires to be achieved which have been determined by standard of the company, In addition of this aspect is so that employees can also increase motivation in increasing results they achieve. 


\section{CONCLUSION}

The study results show that management digitalization can be applied to state owned water company. It also allows the company to keep abreast of new technology developments, changes in organization, workforce and competencies in company management.

Based on above discussion regarding digitalization of company value, there are several solutions related to problem of digitizing corporate value. The first is about openness, which means that when there is information from superiors regarding company changes, regulations, technology updates or other matters, a manager must immediately inform other subordinates. So that it will result in rapid integration and the company's progress quickly in facing digital challenges.

Furthermore, the company must be able to remove or ignore the barriers that prevent company from making changes.

Before implementing renewal of company value, it is recommended that companies be able to experiment for at least 3 to 6 months. In order to find out strengths and weaknesses of the new digital-based corporate values, this can also be used as an adaptation of a company in facing new things.

Finally, it should be noted that renewal of digitalization of corporate value cannot solve all problems that exist in company. However, in this context, digitalization can be used as a spur to increase provitability and increase company performance.

\section{REFERENCES}

Alexander H. Leighton. (1949). Human Relations in a Changing World: Observations on the Uses of the Social Sciences.

Alvarez, S. A., \& Busenitz, L. W. (2001). The entrepreneurship of resource-based theory. Journal of Management, 27(6), 755-775. https://doi.org/10.1177/014920630102700609

Antonio Argandona. (2002). Foresting Values in Organizations. IESE Business School, 6(4), 483. https://doi.org/10.13343/j.cnki.wsxb.2010.09.016

Baehr, J. (2013). The structure of? August, 153-178. https://doi.org/10.1090/gsm/146/03

Bloching, B., Leutiger, P., Oltmanns, T., Rossbach, C., Schlick, T., Remane, G., Quick, P., \& Shafranyuk, O. (2015). Die digitale Transformation der Industrie. Was sie bedeutet. Wer gewinnt. Was jetzt zu tun ist. Roland Berger Strategy Consultants and BDI.

Bob Aubrey. (2010). Managing Your Aspirations: Developing Personal Enterprise in the Global Workplace. McGraw-Hill.

Brinkley RW. (2013). The case for values as a basis for organizational culture. Front Health Serv Manage, 10(1), 3-13.

Browning, M. (2018). Self-Leadership: Why It Matters.

Chemers, M. (1997). An integrative theory of leadership. Lawrence Erlbaum Associates, Publishers.

Chesbrough, H. (2010). Business model innovation: Opportunities and barriers. Long Range Planning, 43(2-3), 354-363. https://doi.org/10.1016/j.lrp.2009.07.010

Chin, R. J. (2015). Examining teamwork and leadership in the fields of public administration, leadership, and management. Emerald Group Publisher Limited, 21(3/4), 199-216. http://dx.doi.org/10.1108/TPM-07-2014-0037\%0ADownloaded

e2consulting. (2020, October 22). Pengembangan Kompetensi di Era Transformasi Digital. E2consulting.Co.Id. https://e2consulting.co.id/2020/10/22/pengembangan-kompetensi-diera-transformasi-digital/

Evan Tarver, \& Brock, T. (2020). Interpersonal Skills. Investopedia.Com. https://www.investopedia.com/terms/i/interpersonal-skills.asp\#: :text=Interpersonal skills are the behaviors,listening to attitude and deportment.

Ferrari, A. (2013). Digital Competence in Practice: An Analysis of Frameworks. Joint Research Centre of the European Commission., 91. https://doi.org/10.2791/82116

Fitzgerald, G. A., \& Desjardins, N. M. (2004). Organizational Values and Their Relation to Organizational Performance Outcomes. Atlantic Journal of Communication, 12(3), 121-145. https://doi.org/10.1207/s15456889ajc1203_1

Fryer, K. J., Antony, J., \& Douglas, A. (2007). Critical success factors of continuous improvement in the public sector: A literature review and some key findings. TQM Magazine, 19(5), 497- 


\section{7. https://doi.org/10.1108/09544780710817900}

Gauthier, C., Bastianutti, J., \& Haggège, M. (2018). Managerial capabilities to address digital business models: The case of digital health. Strategic Change, 27(2), 173-180. https://doi.org/10.1002/jsc. 2192

Gerasimenko, V., Razumova, T., \& Echenike, V. (2015). Rethinking Further Professional Education: Search for Multidisciplinary and New Technological Approaches. IATED, 9th Intern(2-4 March, 2015), 3270-3276. https://library.iated.org/view/GERASIMENKO2015RET

Gerasimenko, V. V., \& Razumova, T. O. (2020). Digital competencies in management: A way to superior competitiveness and resistance to changes. Serbian Journal of Management, 15(1), 115-126. https://doi.org/10.5937/SJM15-23865

Giese, J. L., \& Cote, J. A. (2002). Definining Customer Satisfaction. Academy of Marketing Science Review, 2000(1), 27. http://www.amsreview.org/articles/giese01-2000.pdf

Iman, I. (2020). Ketahui Cara Membuat Action Plan yang Benar untuk Mencapai Target Perusahaan. Sentralsistem.Com, 1. https://sentralsistem.com/news/detail/ketahui-caramembuat-action-plan-yang-benar-untuk-mencapai-target-perusahaan\#: :text=Target adalah suatu sasaran yang,\%25 menjadi 3\%2C6 miliar.

Kwong, J. M. C. (2016). Open-Mindedness as a Critical Virtue. Topoi, 35(2), 403-411. https://doi.org/10.1007/s11245-015-9317-4

Linz, C., Müller-Stewens, G., \& Alexander Zimmermann. (2017). Radical Business Model Transformation: Gaining the Competitive Edge in a Disruptive World. Kogan Page Limited.

Matzler, K., Bailom, F., von den Eichen, S. F., \& Anschober, M. (2016). Digital Disruption. Wie Sie Ihr Unternehmen auf das digitale. Zeitalter vorbereiten.

Özçelik, G., Aybas, M., \& Uyargil, C. (2016). High Performance Work Systems and Organizational Values: Resource-based View Considerations. Procedia - Social and Behavioral Sciences, 235(October), 332-341. https://doi.org/10.1016/j.sbspro.2016.11.040

Palanski, M. E., \& Yammarino, F. J. (2011). Impact of behavioral integrity on follower job performance: A three-study examination. Leadership Quarterly, 22(4), 765-786. https://doi.org/10.1016/j.leaqua.2011.05.014

Pięta, P. (2018). Development of Social Capital By Strengthening of Digital Competences Among Groups Exposed To Social Exclusion. Annals of Marketing Management and Economics, 4(1), 73-87. https://doi.org/10.22630/amme.2018.4.1.6

Pine, B. J., Victor, B., \& Boynton, A. C. (1993). Making mass customization work. Hardvard Business Review.

Riggio, R. . (2009). Introduction to industrial/organizational psychology. Pearson Education, Inc.

Riyanti Etania. (2020). Implementasi Manajemen Modern Di Organisasi. HR Note.Asia. https://id.hrnote.asia/orgdevelopment/modernmanagement-200608/

Ryan, R. M., \& Deci, E. L. (2000). Intrinsic and Extrinsic Motivations: Classic Definitions and New Directions. Contemporary Educational Psychology, 25(1), 54-67. https://doi.org/10.1006/ceps.1999.1020

Schein, E. H. (2004). Organizational Culture and Leadership (Third edit). Jossey-Bass.

Serafica Gischa. (2020). Pengertian Kemandirian, Tahap Perkembangannya dan Faktornya. Kompas.Com. https://www.kompas.com/skola/read/2020/03/02/190000869/pengertiankemandirian-tahap-perkembangannya-dan-faktornya?page=all\#: :text=Artinya kemandirian adalah kesiapan dan,mengarahkan tingkah laku menuju kesempurnaan.

Simanjuntak, B., \& I. L Pasaribu. (1990). Membina dan Mengembangkan Generasi Muda. Tarsito.

Unruh, G., \& David Kiron. (2017). Digital Transformation on Purpose. MIT Sloan Management Review. https://sloanreview.mit.edu/article/digital-transformation-on-purpose/

Westerman, G., Claire Calméjane, Didier Bonnet, Patrick Ferraris, \& Andrew McAfee. (2011). Digital Transformation: A Roadmap For Billion-Dollar Organizations. MIT Center for Digital Business Capgemini Consulting. https://doi.org/10.4028/www.scientific.net/KEM.726.460

Yasril, Y., \& Nur, A. (2018). Partisipasi Masyarakat Dalam Pemberdayaan Lingkungan. Jurnal Dakwah Risalah, 28(1), 1. https://doi.org/10.24014/jdr.v28i1.5538 
